\begin{abstract}
José Carlos Rovira
Catedrático de Literatura Hispanoamericana en la Universidad de Alicante. Ha publicado numerosos estudios y ediciones sobre autores y movimientos literarios españoles e hispanoamericanos, entre ellos, Miguel Hernández, Pablo Neruda, José María Arguedas, poesía novohispana, Ilustración e Inquisición en América, reflexiones en torno a la identidad cultural, etc. En la actualidad ha centrado sus investigaciones en la literatura del período colonial hispanoamericano.
\end{abstract}

\section{Remedios Mataix}

Profesora de Literatura Hispanoamericana en la Universidad de Alicante. Su actividad docente e investigadora ha dedicado una atención especial a la literatura cubana y sus relaciones con los procesos políticos y culturales del siglo XX. Ha dedicado varios artículos y libros a la obra de José Martí y, sobre todo, de José Lezama Lima y el Grupo Orígenes. Actualmente orienta su investigación hacia la literatura colonial y, en concreto, a la obra del Inca Garcilaso de la Vega.

José Lezama Lima y la fundación imaginaria de la literatura colonial cubana

JOSÉ CARLOS ROVIRA REMEDIOS MATAIX

\title{
JOSÉ LEZAMA LIMA Y LA FUNDACIÓN IMAGINARIA DE LA LITERATURA COLONIAL CUBANA
}

\author{
JosÉ CARLOS ROVIRA Y REMEDIOS MATAIX
}

La tradición, como en la célebre frase sobre la libertad, es un don, pero es también una conquista. José Lezama Lima

Hablamos desde la perspectiva de una cultura emergida con fuerza desde el siglo XIX, todavía en el período de la Colonia, acrecentada con pasión en la Independencia - la pasión intelectual de José Martí, por ejemplo-, y rotunda en el siglo que llevamos desde aquel 1898: Cuba es, con tantos países de Latinoamérica, un espacio privilegiado de emergencias múltiples y universales. Pero hablamos precisamente desde la perspectiva de un tiempo no emergente que es el de la casi inexistencia de una tradición literaria durante los siglos de la Colonia.

La cuestión inicial que queremos señalar es efectivamente ese problema de lo casi inexistente. Hasta la Ilustración cubana, casi hasta el libro Llave del nuevo mundo de José Martín Félix de Arrate, a mediados del siglo XVIII, rastreamos con dificultad la literatura culta en Cuba. Otro problema es el de las tradiciones populares, el romancero o la cultura global de la negritud. Pero textos literarios impresos no hay, y además no puede haber en Cuba hasta 1721, que es cuando se establece en La Habana la primera imprenta. Si no hay imprenta no habrá literatura impresa y eso explica, no que ésta no pudiera haber sido escrita, sino que difícilmente se pudiera preservar por el resguardo de la letra impresa. Un texto como el renombradísmo Espejo de paciencia de Silvestre de Balboa, que abre el siglo XVII, y cuya transmisión impresa es un efecto muy posterior, es el único soporte conocido de esa literatura colonial que buscamos previa a la de la sociedad ilustrada.

\section{CUBA Y LA CARENCIA DE UNA TRA- DICIÓN LITERARIA}

Si la Isla de Cuba fue el enclave inicial de la Conquista, si muy pronto en ella se establece un espacio de colonización necesaria como puerta para la llegada al Continente de los conquistadores y colonizadores, ¿por qué no tenemos una sociedad que, como la que se conforma a partir de 1520 en Nueva España (México) y poco después en el virreinato del Perú, cree entre sus establecimientos civiles la imprenta, la Universidad y una capa de intelectuales y escritores capaces de dar cuenta desde el principio de una producción literaria, de realizar la misma? El fenómeno parece obvio y determinante. La Imprenta está en México desde 1530 y, sin embargo, en Cuba casi dos siglos después. En 1519 Cortés decide la refundación de Tenochtitlán, como México, en el mismo espacio en el que había destruido la ciudad azteca tras su guerra de dos años con Moctezuma. Pero ese mismo año, a bastantes millas de distancia, se producía la tercera fundación de la Villa de San Cristóbal de la Habana en la costa norte de Cuba, trasladada desde la costa sur donde en 1514 se había fundado por primera vez. Y empezaron años prometedores pero difíciles para la corona española en Las Antillas. La rivalidad con Francia, las guerras con el país vecino, se trasladaron 
también al Caribe. La piratería asediaba el codiciado puerto de San Cristóbal de La Habana. En 1537 la villa es saqueada y quemada por primera vez por la piratería que sirve a Francia para romper la hegemonía comercial que España está teniendo. En 1555, otro filibustero francés, Jacques de Sores, arrasa e incendia de nuevo San Cristóbal. A partir de aquí, ingleses y holandeses entran en la contienda para dominar el puerto crucial de entrada a América. Allí se abastecen los barcos para retornar hacia el Sur de España con su cargamento de oro. Francis Drake, Robert Baal o Henry Morgan son nombres conocidos de sucesivos asedios.

La destrucción de 1537 intenta repararse con audacia. La corona española nombra a Hernando de Soto capitán general de Cuba y adelantado en la Florida. Dos años ejercerá de capitán general antes de su aventura en $\mathrm{La}$ Florida quien tiene como objetivo fortificar San Cristóbal y la isla. La construcción de $\mathrm{La}$ Fuerza en el puerto de La Habana se inicia en 1539. Las instrucciones de la corona le pedían a De Soto que intentase «un cortijo a manera de ciudadela en el morro que está cerca del puerto». De Soto debía estar pensando en otras cosas. En la joven Inés de Bobadilla, en la búsqueda de la fuente de la eterna juventud para contrarrestar la diferencia de edad con su enamorada, o en la aventura de La Florida que lo debía convertir en otro capitán glorioso como el afamado Cortés. Decidida la construcción de La Fuerza, a trescientos pasos del actual Castillo de La Real Fuerza, partió para la Florida en 1539, dejando a Mateo Aceituno como maestro mayor de obras quien a partir de 1540 sería alcaide de una fortaleza que acabó siendo bastante inútil. Pero esta historia inicial de la fortificación de la isla, diremos, no tiene más objetivo que entrelazar desde el comienzo unos nombres que sí fueron literarios y fundacionales. Y presentar la realidad de la Isla fortificada y amenazada.

No parece que fuera el acoso de la piratería al mayor puerto de comercio, ni la llegada de aventureros que a partir de allí iban a buscar otras tierras de promisión, o permanecían en las encomiendas a las que muy pronto iba a nutrir, por la mortandad de indígenas, el componente importado y esclavo de la negritud, terreno abonado para conformar una sociedad estable que pudiera dedicarse a labores intelectuales. La llave del nuevo mundo era un terreno inestable civilmente, un lugar de paso en sus ciudades principales, un lugar peligroso por el asedio marítimo al que fue sometido. Las fortalezas, la Real Fuerza comenzada a construir hacia 1558, o el Fuerte de San Salvador de la Punta, o el Castillo de los Tres Reyes del Morro, construidos a final de siglo dan cuenta del alto significado militar de la ciudad y del uso de grandes recursos para este fin.

\section{SIN EMBARGO SÍ HAY UNA LITERATURA FUNDACIONAL}

Ocurre necesariamente con la literatura cubana, como en toda la tradición hispanoamericana, que su fundación se realiza en el descubrimiento y en las tradiciones previas existentes de las antiguas civilizaciones. En Cuba, al contrario que en México y Perú, no hay una articulación cultural consistente previa. Es decir, no afloran vestigios de una civilización precolombina. Los pueblos indígenas que existían, esa población de unos cien mil individuos que despareció casi totalmente en la dureza de la avidez conquistadora, los taínos, subtaínos y guanahatabeyes, distribuídos por el territorio como pueblos agrícolas y cazadores, no habían afianzado ni desarrollado un sistema cultural comparable a la grandeza de los pueblos de México o de la cordillera andina.

El descubrimiento sin embargo nos ofrece los primeros textos culturales sobre la Isla, en una fundación que tiene los mismos parámetros organizadores que los de la literatura hispanoamericana, pues varias de las voces principales de la crónica del siglo XVI se afincan en tres discursos principales: el originario y fundacional de Colón, el de la violencia de Fray Bartolomé de las Casas y, cerrando el siglo, las primeras evocaciones urbanas de la isla a través del Inca Garcilaso de la Vega. Colón, Fray Bartolomé y Garcilaso, paradigmas esenciales de la crónica de Indias en tres líneas principales, son los fundadores de la escritora sobre el espacio de Cuba. Pero epor qué no hablar, co-
José Lezama Lima y la fundación imaginaria de la literatura colonial cubana

JOSÉ CARLOS ROVIRA REMEDIOS MATAIX 
José Lezama Lima, «Preludio a las eras imaginarias» (1958) en Las eras imaginarias, Madrid, Fundamentos, 1971, pág. 22.

\section{2}

José Lezama Lima, Prólogo a An tología de la poesía cubana, La Habana, Consejo Nacional de Cultura, 1965, 3 vol. Lo tomo de Confluencias. Selección de ensayos, Selección y prólogo de Abel Prieto, La Habana, Editorial Letras Cubanas, 1988, pág. 101.

3

Cristóbal Colón, Textos y documentos completos, edición de Consuelo Varela, Madrid, Alianza Universidad, 1984, pág. 21.

4

Confluencias, cit. pág. 101.

5

José Lezama Lima, «Paralelos. La pintura y la poesía en Cuba (siglos XVIII y XIX), Casa de las Américas, 7(41), marzo-abril 1967. Lo recojo de La cantidad hechizada, Madrid, Júcar, 1974, págs. 7-8.
José Lezama Lima y la fundación imaginaria de la literatura colonial cubana

JOSÉ CARLOS ROVIRA REMEDIOS MATAIX mo haría seguramente José Lezama Lima, de fundadores de la literatura cubana?

\section{JOSÉ LEZAMA LIMA Y SU FUNDA- CIÓN IMAGINARIA}

De las distancias que José Lezama Lima nos produjo, cuando leíamos disciplinadamente Paradiso a fines de la década de los sesenta o en años posteriores, de las incomprensiones que determinaron la primera lectura de su poesía, hemos podido pasar algunos al apasionamiento con una obra ensayística, poética y narrativa que forma un sistema coherente de creación y pensamiento. Con la misma coherencia poética que La ciencia nueva de Vico — de la que Lezama se sentirá deudor afirmando sus posiciones contra el racionalismo de Cartesio, citado siempre así en obvia concesión a la tradición clásica del nombreLas Eras imaginarias de Lezama construyen un universo posible y repleto de signos, que no mueren pues son «señales» y la señal, dice Lezama:

comienza en la teoría o desfile a hora y júbilo señalados. En la vacilación del cortejo por aparecer, en la prosecución de la pareja, en el solitario deseado coincidente, también el signo rubrica la posibilidad de la aparición'1.

Una poética de lo imaginario avant la lettre, y no establecida en el sentido de la moderna teoría del imaginario, sino a través del entrelazamiento de lo posible, conforma una aventura intelectual nutricia y repleta de sugerencias. En ella, Lezama, entre tantas otras fundaciones, se apresta a la del pasado de $\mathrm{Cu}$ $\mathrm{ba}$, recorriendo signos poéticos posibles, señales, en un cortejo que tiene en su aparición los nombres que establecimos antes: Colón o Hernando de Soto, por ejemplo:

Nuestra Isla comienza su historia dentro de la poesía. La imagen, la fábula y los prodigios establecen su reino desde nuestra fundamentación y el descubrimiento. Así el Almirante Cristóbal Colón consigna en su Diario, libro que debe estar en el umbral de nuestra poesía, que vio caer, al acercarse a nuestras costas, un gran ramo de fuego en el mar. Ya comenzaban las seducciones de nuestra luz².

El episodio citado por Lezama es sencillo y se refleja en el diario del primer viaje de Co- lón, el 15 de septiembre de 1492, exactamente así:

Navegó aquel día con su noche XXIII leguas su camino al Güeste y algunas más. Y en esta noche al principio d'ella vieron caer del çielo un maravilloso ramo de fuego en la mar, lexos d’ellos cuatro o cinco leguas?3.

Otras imágenes recorren el texto fundacional, hasta llegar a una primera propuesta:

En esos primeros años del descubrimiento, la imaginación y la realidad se entrelazan, los confines entre la fabulación y lo inmediato se borran ${ }^{4}$.

Estamos ya ante una poética fundacional construida a través de un fenómeno descrito en 1492 por Colón que se entrelaza a una metáfora sobre la luz en Cuba. Ya tenemos un texto originario por tanto. Una era imaginaria aparece en una era histórica y José Lezama Lima no dejará de insistir en ella.

Otro ejemplo que además nos divierte. Les vamos a introducir brevemente en otra era imaginaria a propósito del episodio fundacional que acabamos de narrar. Se trata del comienzo de «Paralelos. La poesía y la pintura en Cuba» ${ }^{5}$. Es de 1966. El texto dice así:

Antes de saltar embebido las clavijeras amarras, el misterioso surcador Cristóbal Colón se aposenta demorado frente a unos tapices: $\mathrm{Ha}$ cruzado una poderosa llanura, lo que debe haberle producido la sensación de una navegación inmóvil, está en un extremo de Castilla la Vieja y entra para oír misa de domingo en la Catedral de Zamora. Siente la grandeza de uno de los más hermosos tapices que existen, que compite con dignidad castellana con La dama y el unicornio, de Cluny. Uno de los tapices entreabre las guerras de Troya, con el rapto de Elena. En el centro, una barca medieval de gran tamaño, los mástiles ganan la altura del tapiz, aparece un marinero de extraña catadura, muy barbado, soltando el ancla, otro marinero recoge las amarras. Rimas provenzales limitan el panel, en torno del mástil, como palomas. Después está la tienda de Aquiles, en su fondo el ulular de la batalla. Bosque de lanzas y estandartes, abriéndose en el bosque los ojos de las damas para contemplar las murallas de Ilión. El caballo blanco de Aquiles, un doncel rubio sostiene las riendas. Alternan cerca de la tienda los griegos y los orientales, más parecen susurrar sus murmuraciones los comerciantes, que su vanagloria los guerreros. Las ropas son de nobles bi- 
zantinos, algunas parecen venidas de Catay o de $\mathrm{Ci}$ pango. Un grupo de damas contempla aisladamente a un caballero, que penetra en el mar de los combatientes con un desenfado singular. En los otros tapices las muertes de Aquiles, Troilo y Paris. Los caballos se recubren con unas gualdrapas tan guarnecidas como el manto que cubre el elefante de un rajá. Aparecen curvados barcos, como góndolas de la serenísima. Debajo de los muros y las ruinas estallan las flores como llamas torneadas. Un caballero pisotea las rosas de más sonriente amanecer. Las interminables llanuras de flores se confunden con las más presuntuosas alfombras persas con motivos de venatoria. Cuando el Almirante va recogiendo su mirada de esos combates de flores, de esas escaleras que aíslan sus blancos como aves emblemáticas, del arquero negro cerca de la blancura que jinetea Tanequilda, y las va dejando caer sobre las tierras que van surgiendo de sus ensoñaciones, se ha verificado la primera gran transposición de arte en el mundo moderno. De esos tapices ha saltado a tierra, y los blancos fantasmales, las cabelleras de las doncellas y los arqueros sombríos han comenzado a perseguirlo y arañarlo.

Las imágenes reafirman la propuesta de Lezama. Colón ha entrado a misa dominical en la catedral de Zamora y unas imágenes le asaltarán para siempre, se convertirán en una compañía que salta con él a la tierra americana: blancos fantasmales, cabelleras de doncella y arqueros sombríos le persiguen para siempre. O las ropas de estos griegos que parecen venidas de Catay o de Cipango. Todo un salto en un vacío imaginario y fundacional, en una transposición artística que tiene que ver con la fusión del imaginario europeo (aunque habla de «la dignidad castellana» de los tapices) y las nuevas tierras recién descubiertas.

La propuesta de Lezama es básica, como sabemos, para un programa artístico de rescate del pasado, para convertir al mismo en «materia artizable»:

Entre nosotros es casi imposible configurar una tesis o un punto de vista aproximativo sobre nuestro pasado, ya de poesía, ya de pintura, porque los diversos elementos larvales aún no se han escudriñado, ni siquiera señalado su regirar ectoplasmático. Si no aparecen las larvas, cómo vamos a abrillantar el caparazón. Lo larval sólo podemos captarlo en sus mutaciones, en su devenir para llegar a ser un cuerpo, una forma, una materia artizable ${ }^{6}$.
Sólo que el escudriñamiento lezamiano de lo larval aquí no parece verdadero, por muy bello que resulte este encuentro dominical de Colón con los tapices zamoranos ${ }^{7}$. O alcanza la dimensión de lo más verdadero, una era imaginaria, en la que el arte de unos tapices hizo su transposición al nuevo mundo en aquel primer encuentro. Lezama sabe seguramente que el encuentro con los tapices es suyo, que no puede estar atestiguado en ninguna parte el del intrépido navegante, puesto que los tapices no están en la Catedral más que desde 1608, por una donación, que consta documentalmente del duque de Alba y Aliste.

Entre las deducciones de dónde podían estar los tapices en la época que cuenta, tapices que Lezama ve en su «dignidad castellana», seguramente estarían en un taller de Tournai, gran centro flamenco de los tapices europeos, puesto que parecen ser del último tercio del siglo $\mathrm{XV}$. O a lo mejor estaban ya en poder de don Íñigo López de Mendoza, conde de Tendilla - el hijo de aquel otro homónimo conocido como marqués de Santillana y gloria de nuestra literatura del XV - cuyo escudo de armas preside las piezas.

No, Colón no pudo ver los tapices que Lezama sitúa como fantasmas para el imaginario en las nuevas tierras. Un desmitificador de Lezama, como Horts Rogmann, diría: «veis, Le-

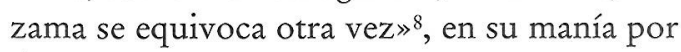
demostrar que Lezama citaba por citar y muchas veces lo hacía mal. Sin darse cuenta, como nos hemos dado cuenta nosotros, de que Lezama nos estaba permitiendo con su error (voluntario) cifrar el imaginario americano en su fusión al imaginario de unos tapices flamencos. Sabemos entonces que es grandiosa su fusión fundacional que nos ha permitido hablar sobre lo inexistente. En cualquier caso, sabemos también que Colón hizo mal en no ver los tapices.

\section{RECORRIDOS POR OTRAS SECUEN- CIAS FUNDACIONALES}

Los caminos fundacionales asumen inmediatamente otras referencias. Puede ser, por ejemplo, Pedro Mártir de Anglería y la evocación de un fragmento de la Isla que aparece en
6 Ibídem, pág. 13.

7

En el texto ya citado Prólogo a Antología de la poesía cubana, pág. 102, atenúa Lezama la seguridad del encuentro: «...cuyos temas aparecen en los bellísimos tapices de la catedral de Zamo$\mathrm{ra}$, que sin duda alguna deben haber sido vistos por Colón e impregnaron poderosamente su fantasía viajera».

8

Horts Rogmann plantea este tipo de "desmitificación» en "Anotaciones sobre la erudición en Lezama Lima», Coloquio Internacional sobre la obra de José Lezama Lima: Poesía, Université de Poitiers, Madrid, ed. Fundamentos, págs. 77-84. 
Lezama, Confluencias, cit., pág. 101-102.

\section{0}

Lezama, Confluencias, cit., pág 104

11

Lezama, Confluencias, cit., pág 106

\section{2}

José Carlos Rovira, «La imagen reflejada en el Espejo de paciencia de Silvestre de Balboa», Coloquio Imágenes recíprocas e imaginarios nacionales (Cuba, Puerto Rico, Filipinas y España) a fines del siglo XIX, Madrid, Casa de Velázquez-CSIC, septiembre de 1998 (en prensa).

13

Lezama, «Introducción a un sistema poético», en Tratados en la Habana (1958). Lo tomo de Confluencias, cit., pág. 334.

14

Lezama, "A partir de la poesía», La cantidad hechizada, La Habana, Unión, 1970, pág. 387.

José Lezama Lima y la fundación imaginaria de la literatura colonial cubana

JOSÉ CARLOS ROVIRA REMEDIOS MATAIX las Décadas, que califica Lezama de «descripción meramente imaginativa»:

...todo es templado de humedad, todo rico en productos acuíferos. Sus cuevas, como tantas bocas abiertas, desembuchan toda el agua de los ríos. Allí hay cavernas horrorosas, hay valles oscuros, hay rocas calcáreas,

para puntualizarnos a continuación:

La visión que tiene de nuestro país este cronista es la de su semejanza con Sicilia, cuyo recuerdo en la realidad y en la mitología está lleno de remolinos, cavernas, ríos, rocas. Se observa la tendencia a tener una perspectiva mitológica, aun en la realidad de lo que le rodea, paisaje, flora, fauna. Así relata Pedro Mártir de Anglería que un manatí fue cogido joven por un cacique haitiano, alimentándolo en sus lagunas. El animal creció amigado con el hombre. Acudía al llamamiento de Mato Mato y venía a comer en las manos. del cacique. Recogía sobre su lomo a hombres y mujeres, y los llevaba a la otra orilla como cuentan de los delfines en el mundo antiguo?.

Transposiciones de paisajes, desde islas europeas a Cuba, o secuencias mitológicas como fundación larval a través de Pedro Mártir de Anglería; o la presencia inmediata en el espacio fundacional de Hernando de Soto:

La imagen se va imponiendo a lo caótico y a la fabulación oscura. Aparece el genitor por la imagen, don Hernando de Soto, el enterrado y desenterrado. $\mathrm{Su}$ imagen sigue engendrando después de muerto [...] Ya a fines del siglo XVI, la imagen creada por el genitor Hernando de Soto tiene un punto de apoyo, la ciudad está presta a su defensa porque tiene el convencimiento de su importancia como llave del país ${ }^{10}$,

recordándolo otra vez en La cantidad hechi$z a d a$, en el episodio de su encuentro en el Castillo de la Fuerza con Juan Ponce de Léon, buscador de la fuente de la eterna juventud; $y$ recorriendo el episodio de De Soto hasta su muerte, la espera por parte de Inés de Bobadilla en la Habana, la muerte de ésta. El Inca Garcilaso le sirve esta vez de apoyatura para este otro fragmento fundacional.

Pero será precisamente a comienzos del siglo XVII donde Lezama situará un episodio menos imaginario en su materialidad textual, aunque más intenso en sus imaginaciones na- cionales: Espejo de paciencia del canario-cubano Silvestre de Balboa, poema que

revela el nacimiento de modos y maneras cubanas, que a pesar de la influencia española tenemos que interpretar como algo cubano que quiere ganar su contorno y tipicidad ${ }^{11}$.

Lezama ha escrito varias veces sobre esta obra, de la que nos dice que «desde que se escribió este poema ya se podía hablar de lo cubano, más que en lo externo en la presencia compleja de la poesía», llegando por tanto a una fundación nacional aislada en 1606 en Manzanillo de Cuba de toda una tradición posible. Recientemente hemos podido privilegiar el poema de Balboa, como base de una lectura acumulativa y crítica que, abriéndose en el siglo XIX y continuándose por todo el nuestro, provocaba que sucesivos lectores se hubieran ido asomando al espejo de Balboa, reflejándose en él y creando con sus reflejos una perspectiva nacional creciente desde el siglo XIX ${ }^{12}$. La idea de aquella reflexión nos la provocó otra vez Lezama Lima con un motivo de partida que decía así:

Está dispuesto José Martí, y es esa su imago más fascinante junto con su muerte, a llenar el contenido vacío de ese espejo de paciencia ${ }^{13}$.

En aquella reflexión comprobamos que Martí no había llenado directamente el espejo de Balboa, pero que la metáfora de llenar el espejo vacío había atraído lecturas nacionales. Y atribuciones erróneas a Martí en relación con esta obra.

\section{POR ÚLTIMO ¿DE QUÉ EMERGENCIA ESTAMOS HABLANDO?}

De lo que hemos estado hablando entonces es de la capacidad de sugerencia inagotable que José Lezama Lima tuvo, también para fundar con retazos larvales una tradición inexistente o desconocida, su capacidad para reinventar lo desconocido porque, como dijo otra vez,

La imantación de lo desconocido es por el costado americano más inmediata y deseosa. Lo desconocido es casi nuestra única tradición ${ }^{14}$.

Las posibilidades son infinitas en su juego imaginario $y$, en todo caso, sirven para des- 
montar, o para montar de nuevo, una época inexistente y convertirla en una imaginaria, junto a su capacidad larvadamente mordaz para desmontar una historia de la literatura chata, codificada y estéril. Todos recordamos aquel momento esencial de Paradiso donde reflexiona sobre la literatura y lo posible, sobre la imaginación en definitiva:

En ese momento Cemí se aprovechó para colocar una banderilla. La crítica ha sido muy burda en nuestro idioma. Al espíritu especioso de Menéndez y Pelayo, brocha gorda que desconoció siempre el barroco, que es lo que interesa de España y de España en América, es para él un tema ordalía, una prueba de arsénico y de frecuente desbarro. De ahí hemos pasado a la influencia del seminario alemán de filología. Cogen desprevenido a uno de nuestros clásicos y estudian en él las cláusulas trimembres acentuadas en la segunda sílaba. Pero penetrar a un escritor en el centro de su contrapunto [...] eso lo desconocen beatíficamente. Por ejemplo, en Góngora, es frecuente la alusión a las joyas incaicas, sin embargo, no se ha estudiado la relación de Góngora con el Inca Garcilaso, en el tiempo en el que ambos coincidieron en Córdoba. Los incas en la imaginación de Góngora; he ahí un delicioso tema. Las verdaderas relaciones de Góngora con el Conde de Villamediana, se desconocen o se silencian, a pesar de las constantes alusiones de Quevedo. La imaginación retrospectiva, tan fundamental como cuando crea mundos o simples planetas fundantes, tiene un placer interminable, los relatos que le hacía el Inca Garcilaso a Góngora de una de las eras imaginarias, la piedra despidiendo imágenes, tienen que ha- ber sobresaltado los sentidos del racionero mayor, en el momento en el que se llevaba una enorme ración para su metáfora y su venablera ${ }^{15}$.

Hemos estado hablando entonces de esa «imaginación retrospectiva», de la emergencia de lo posible, como configuración de sugerencias que, en el caso de la literatura cubana, significaban una reinterpretación de secuencias, fragmentos, hipótesis, invenciones que han sido en nuestro siglo fundacionales. $\mathrm{Ca}-$ ben otros parámetros para adentrarnos en la tradición cubana en la época de la colonia. Hablamos al principio de tradiciones como el romancero y la negritud. Pero José Lezama Lima, desde su obsesión por los orígenes y por su emergencia universal, optó por otra tradición, en cuanto podía fundar a través de ella una universalidad imaginativa e imaginaria en la que pudiera reconocerse también la cultura cubana y universal del próximo siglo. En realidad, no fue otro el proyecto del grupo que él encabezó:

La poesía, lo que ya se puede llamar con evidencia los poetas de la generación de Espuela de plata, querían hacer tradición, reemplazándola, donde no existía (...) Querían que la poesía que se elaboraba fuera una seguridad para los venideros. Si no había tradición entre nosotros, lo mejor era que la poesía ocupara ese sitio, y así habría la posibilidad de que en lo sucesivo mostráramos un estilo de vida ${ }^{16}$.

Lezama dixit.
15

José Lezama Lima, Paradiso, edición de Cintio Vitier, Madrid, Archivos, 1988, págs. 240-241.

16

Lezama, «Después de lo raro, la extrañeza», Orígenes $n^{\circ} 6$ (1945), pág. 52.

José Lezama Lima y la fundación imaginaria de la literatura colonial cubana 
«Antes de saltar embebido las clavijeras amarras, el misterioso surcador Cristóbal Colón se aposenta demorado frente a unos tapices...»

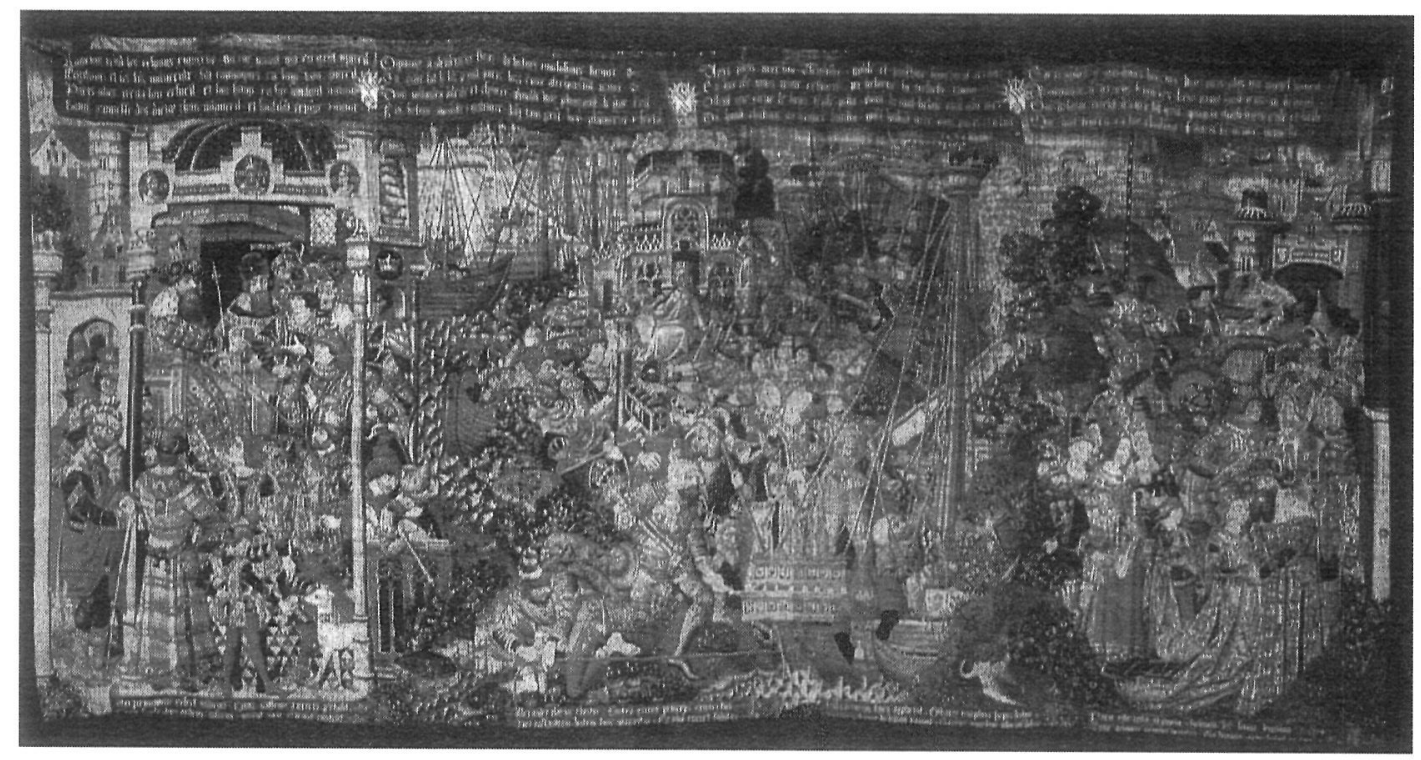

LÁMINA 1. Medidas: 9,30 metros largo × 4,50 metros alto.

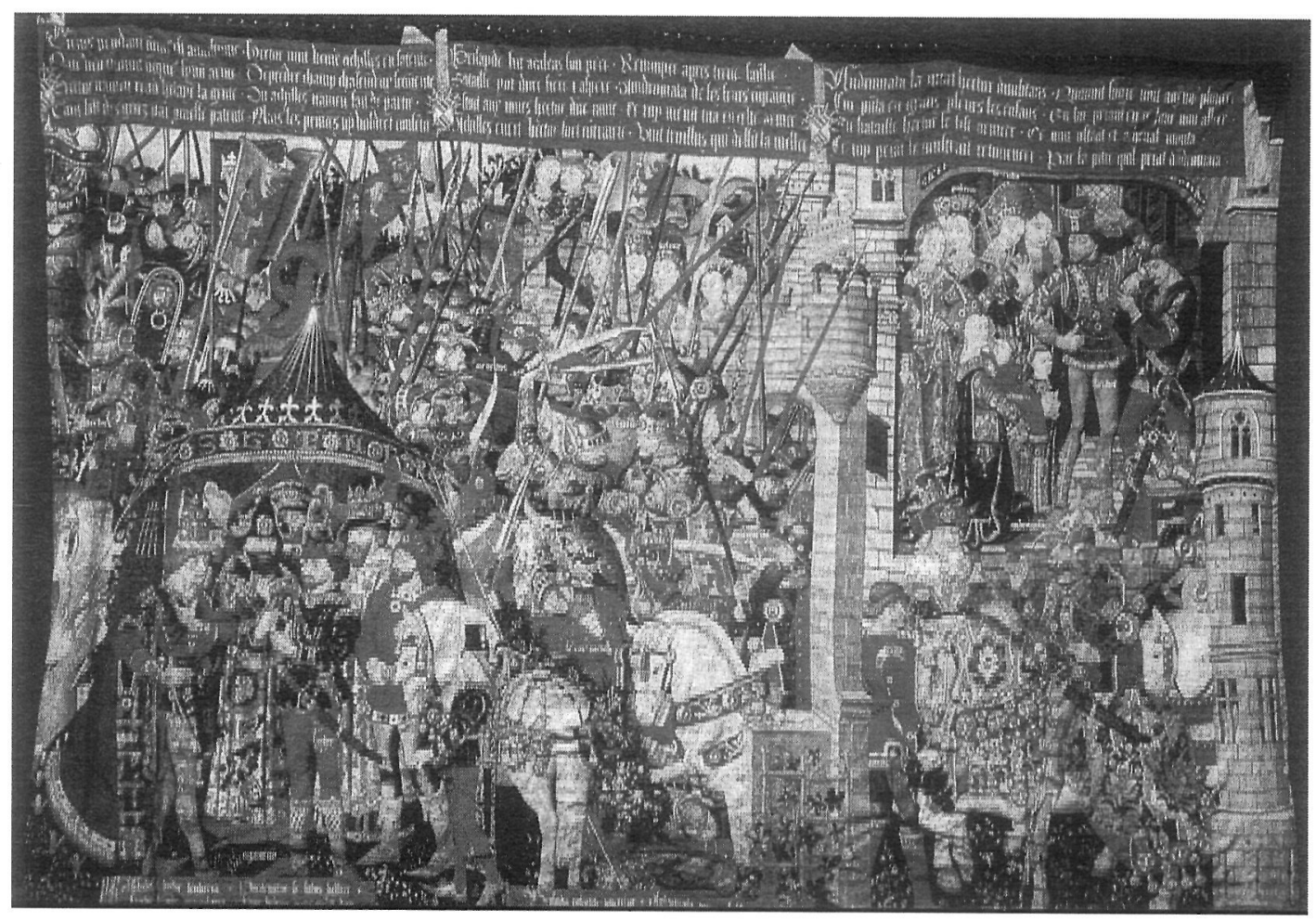

LÁMINA 2. Medidas: 6,90 metros largo × 4,67 metros alto. 
«...De esos tapices ha saltado a tierra... Se ha verificado la primera gran trasposición de arte en el mundo moderno...»

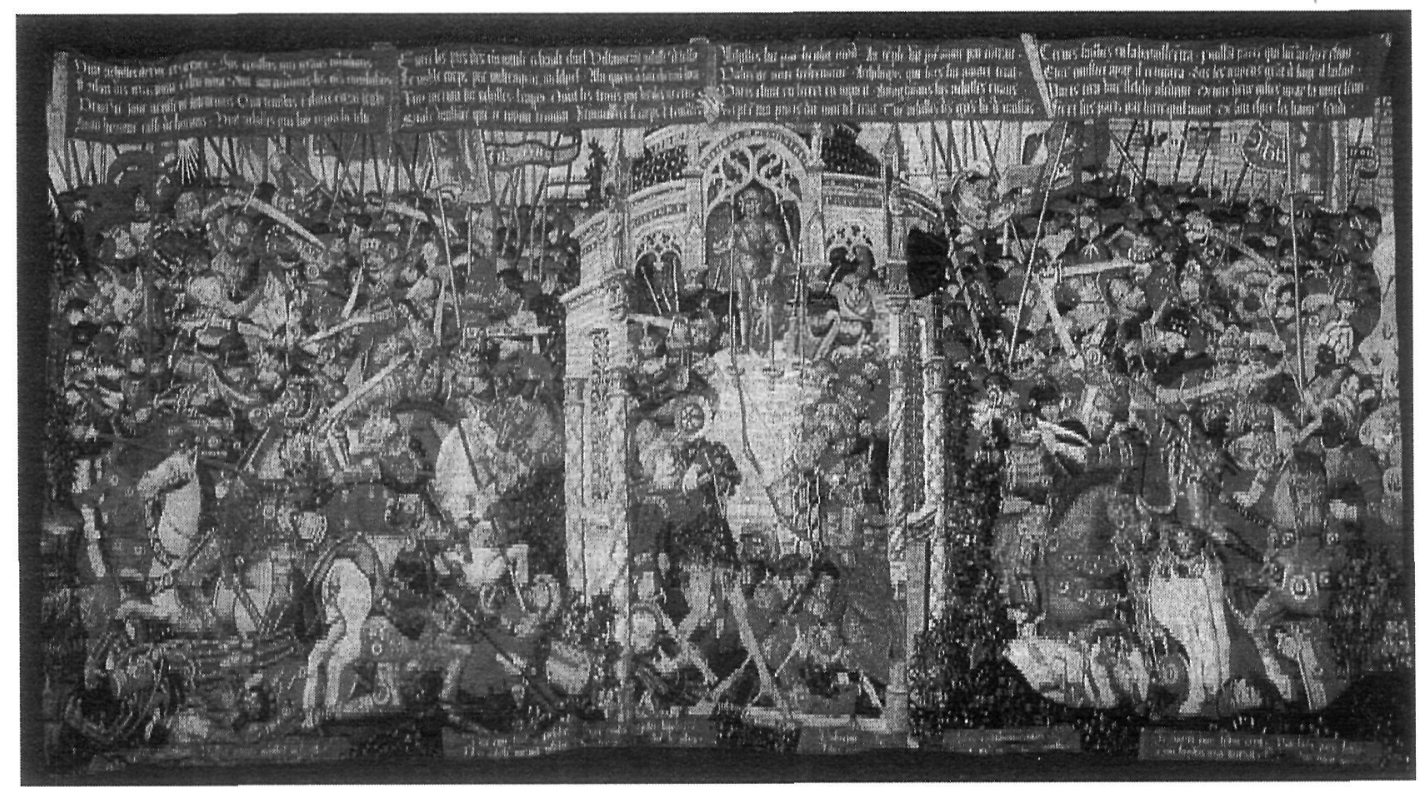

LÁMINA 3. Medidas: 9,42 metros largo x 4,81 metros alto.

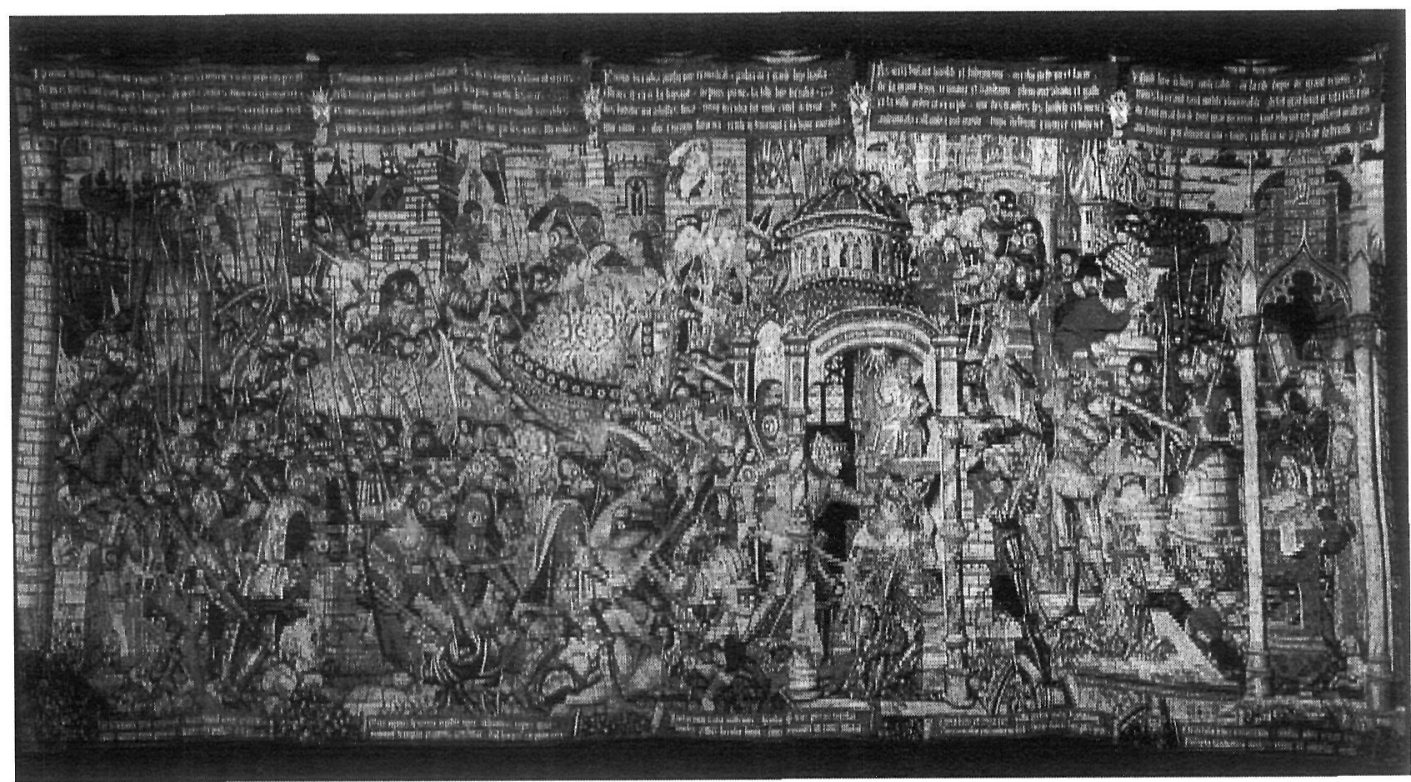

LÁMINA 4. Medidas: 9,42 metros largo x 4,77 metros alto.

José Lezama Lima y la fundación imaginaria de la literatura colonial cubana 